\title{
Analysis of Ship Accidents due to Marine Engine Failure* \\ - Application of Logic Programming Technique (LPT)
}

\author{
Zobair Ibn Awal Kazuhiko Hasegawa**
}

\begin{abstract}
Maritime accident is an issue of immense concern across the globe particularly because of its effect on environment and human lives. In general, there are many contributing factors behind maritime accidents, yet failure of marine engine is regarded as one of the main contributing factors. This paper, therefore, focuses on maritime accident due to engine failure. Literature review suggest that a wide range of accident theories have been developed over the years which can explain the causes of accidents. Nevertheless, there exist a significant deficiencies in computational techniques of accident prediction and analysis. Therefore, the authors attempted to present a new method named Logic Programming Technique (LPT). A simple modelling architecture is proposed which essentially utilizes search techniques to deduce an accident with sequence of events associated with engine failure. In this paper, a static knowledge base is constructed following two actual marine accident cases in order to explicate the concept. The research findings suggest that this technique has the potential to dig deep into the accident sequence and find out the root causes. Future challenges for developing this technique are discussed and research on further advancements are recommended.
\end{abstract}

\section{Introduction}

Around the world marine engine failure is one of the major causes of maritime accidents. Marine engines are part of complicated propulsion system of ships. Failure of such systems yield severe consequence, which have been observed during the accident of MV Bright Field [1][2] in 1996 and accident of MV Planet V [3] in 2012. During a ship's operational lifetime, engine failures are not rare and preparations are always undertaken beforehand to prevent engine failure and catastrophic consequences. However, in such scenarios the operators' decisions play very crucial role, particularly during a voyage. For example, the investigation of the Bright Field accident revealed that if the chief engineer of the ship had manually overridden the engine restart procedure, the accident could have been avoided or the accident could have resulted in less consequence [1]. It could be regarded as a fact that in critical situations, ship crew may make a mistake and accident can occur. However, accidents may also occur due to faulty interaction among the crew members which was

\footnotetext{
*Received August 20, 2015

*** Graduate School of Engineering, Osaka University, 2-1

Yamadaoka, Suita, Osaka 565-0871, Japan
}

observed during the MV Bright Field accident as well [2]. Therefore, the interaction among ship crew and their action with the ship is an area of interest for accident investigators.

This research work, therefore, attempts to investigate a new accident analysis technique. This new approach is called Logic Programming Technique (LPT). This study is an extension of a previous research work [4] of the authors where the fundamentals have been further refined. A literature review is conducted for better understanding of the accident theories and maritime accident analysis. Two accident case studies are then reviewed where the accidents are explained as sequence of events. LPT is then described and utilized. Results obtained from the model run are discussed and conclusions are drawn.

\section{Literature Review}

\subsection{Definition of Accident and Accident Model} One of the earliest definition of accident was given by Heinrich in 1931 which has been referenced by Ward [5]. The definition is "An accident is an unplanned and uncontrolled event in which the action or reaction of an object, substance, person, or 
radiation results in personal injury or the probability thereof'. In other words, an accident is a preventable, unforeseen and un-planned event or circumstance that causes damage and/or injury. However, in addition, an accident model provides a conceptualization of the characteristics of the accident that normally shows the relation between causes and effects [6].

\subsection{Development of Accident Models}

Traditional approach towards accident analysis, maritime accidents in particular, is using statistical tools to study the probability of accident causation with respect to different variables such as weather, geographical features, human elements and others [7][8][9]. Such analysis reveals probable causes of accidents. However, since early twentieth century, researchers initiated developing accident models [6][10]. Study reveals that accident models have evolved as the interaction between man and machine changed over time. It is interesting to note that different branches of knowledge (such as ergonomics and human factors, organization theory, industrial psychology, medicine, environmental sciences, law etc.) can be utilized to explain accident phenomena. From the accident causation perspective, these fields are overlapping and originate complexities. Therefore, the accident modelling techniques are diversified and distinct from each other. Qureshi [6] and Khanzode et. al.[10] reviewed accident/injury theories and made respective classifications. For example, Khanzode at. al. [10] classified the accident models as follows:

1. 1st Generation: Accident proneness based

2. 2nd Generation: Domino theory based

3. 3rd Generation: Injury epidemiology based

4. 4th Generation: System based

The study by Qureshi [6] reveals another type of classification of accident models. According to this study there are three major types of accident models:

1. Traditional approaches to accident modelling (sequential models)

2. Epidemiological/Organizational models of accident causation

3. Systemic accident models

A study by Awal and Hasegawa [11] explored the chronological order of development and classification of accident models all together, as shown in Fig. 1. The study shows that in recent time more complex system theoretic models are proposed compared to earlier sequential/epidemiological models. Most of the modern day accident models adopt the fact that accident takes place in a complex sociotechnical system in order to combine the social and technical attributes in the analysis [6][10]. Most models are subjective by nature and requires extensive brainstorming for producing applicable results. So far very little computational techniques have been developed that can efficiently analyze accidents in a computer programming environment. Such technique is believed extend the capacity of an accident analyst and improve safety as well.

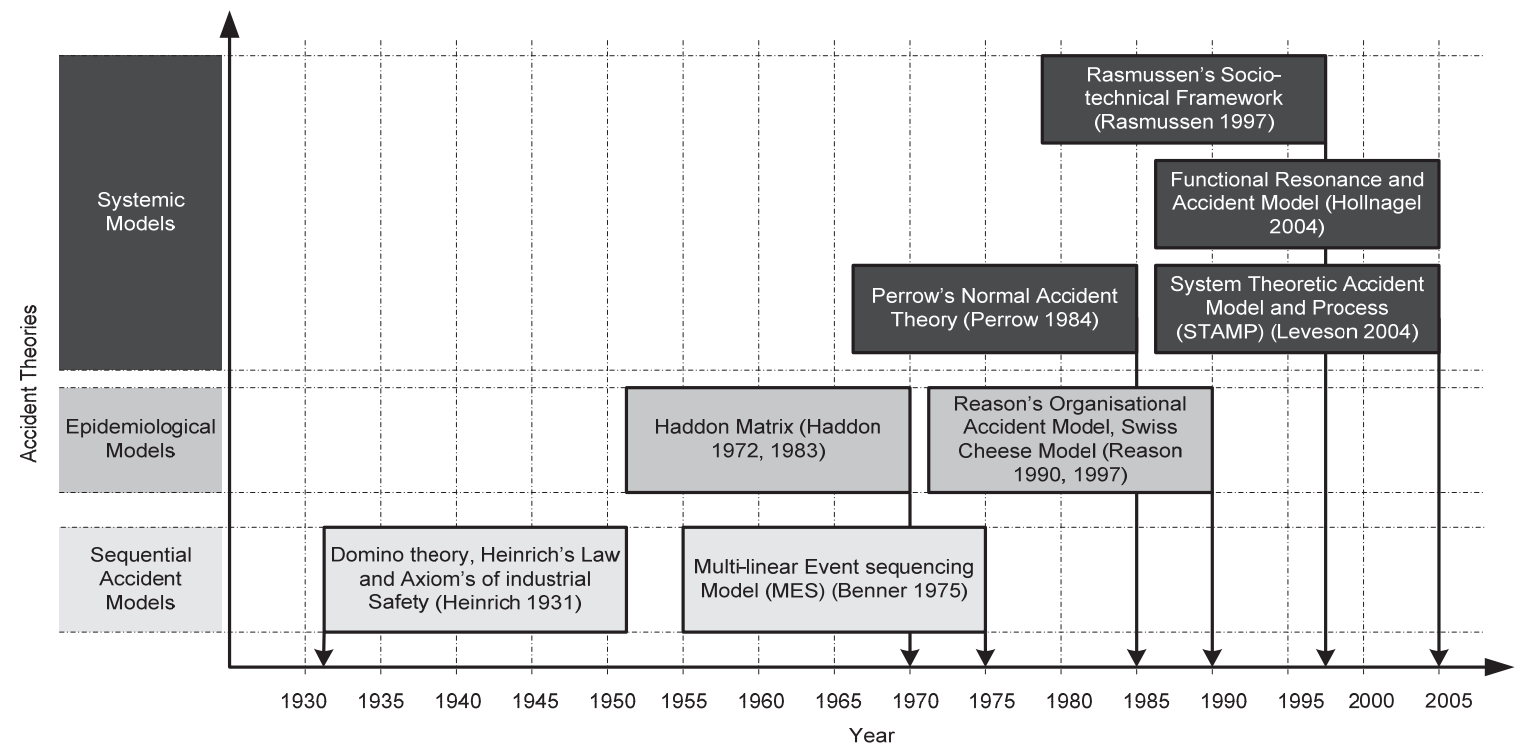

Fig. 1: Development of accident models in chronological order [11]. 
Recent studies by Awal \& Hasegawa [4] [11-14] and Hasegawa \& Awal [15] describes the need for and progress of such an approach. Therefore, this study extends the previous research works and attempts to apply LPT to engine failure related maritime accidents.

\section{Case Study: Two Accident Cases}

In this research work two accident cases have been selected and investigated for the logic program model. The first accident case is the accident of MV Bright Field which occurred at the Mississippi river, New Orleans, Louisiana on 14th December 1996. The second accident case is the accident of MV Planet V which collided with a pontoon at Westerschelde, The Netherlands on 26th of May 2012. The similarity between these two accidents is that both accidents involve engine failure which combined with human decisions resulted in collision/allision. Using logical arguments it is demonstrated here in this paper that how both of the accidents were avoidable.

\subsection{Accident of MV Bright Field}

The accident of MV Bright Field took place shortly after 1400 hrs on December 14, 1996. The fully loaded Liberian bulk carrier temporarily lost propulsion power as the vessel was navigating outbound in the Lower Mississippi River at New Orleans, Louisiana. Total property damages to the Bright Field and to shore side facilities were estimated at about $\$ 20$ million [2]. According to the report [1] it was found that the ship had problems with its engine lube oil system prior to few days of the accident. On the open sea, in good weather, temporary malfunctions in the vessel's main engine may be tolerable; however, in the close quarters of the Mississippi River, where safe maneuvering is directly dependent upon a responsive main engine, a loss of power can, as it did in this instance, present an immediate threat to other vessels and to shore side facilities. Using the information available for the final 6 minutes before the accident a time history of events can be constructed as shown in Table 1.
Table 1: Time history of events for the last six minutes of MV Bright Field [1][2].

\begin{tabular}{|c|c|c|c|c|}
\hline Comments & Time & Person & $\begin{array}{l}\text { Observation/ } \\
\text { Activity/Decision }\end{array}$ & Situation \\
\hline \multirow{8}{*}{ 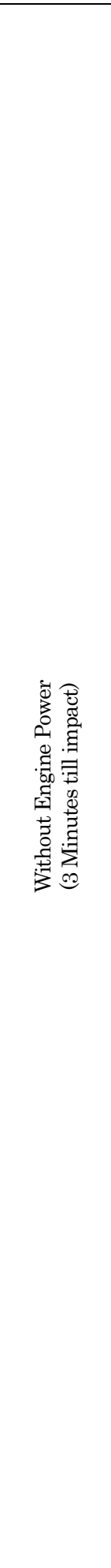 } & 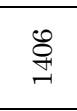 & & $\begin{array}{l}\text { Engine power } \\
\text { drops. }\end{array}$ & $\begin{array}{l}\text { Bright Field } \\
\text { passing under } \\
\text { a bridge. }\end{array}$ \\
\hline & ț & 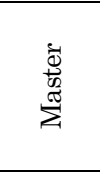 & $\begin{array}{l}\text { Asks his mate to } \\
\text { call engine room } \\
\text { and demand an } \\
\text { increase in } \\
\text { power. }\end{array}$ & \\
\hline & 常 & 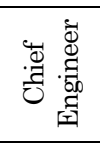 & $\begin{array}{l}\text { Thinks except } \\
\text { for the low rpm } \\
\text { everything is } \\
\text { normal. }\end{array}$ & $\begin{array}{l}\text { He possibly } \\
\text { thinks the low } \\
\text { rpm is from the } \\
\text { bridge control. }\end{array}$ \\
\hline & 㕝 & 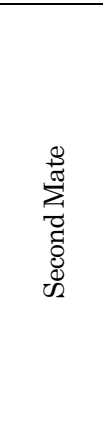 & $\begin{array}{l}\text { The second mate } \\
\text { calls the Chief } \\
\text { Engineer and } \\
\text { demands } \\
\text { increase power. } \\
\text { But he doesn't } \\
\text { relay the } \\
\text { information of } \\
\text { ship's heading } \\
\text { and } \\
\text { maneuvering } \\
\text { situation to the } \\
\text { Chief Engineer. }\end{array}$ & $\begin{array}{l}\text { It seems the } \\
\text { danger of } \\
\text { collision or } \\
\text { allision is not } \\
\text { comprehended. } \\
\text { Perhaps both } \\
\text { the Master and } \\
\text { the Second } \\
\text { Mate thought } \\
\text { the engine } \\
\text { power would be } \\
\text { back soon. }\end{array}$ \\
\hline & 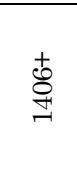 & 岂 & \multicolumn{2}{|c|}{$\begin{array}{l}\text { As the Chief Engineer doesn't } \\
\text { perceive any danger, he suggests } \\
\text { transfer of engine control from } \\
\text { wheelhouse to engine control room } \\
\text { as a usual practice. }\end{array}$} \\
\hline & 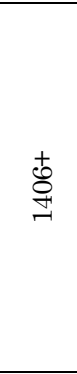 & 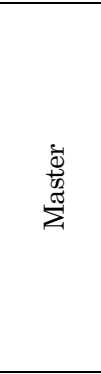 & $\begin{array}{l}\text { As the Master } \\
\text { doesn't know } \\
\text { about the } \\
\text { particular cause } \\
\text { of the problem, } \\
\text { he agrees to } \\
\text { transfer the } \\
\text { control to the } \\
\text { engine room. }\end{array}$ & $\begin{array}{l}\text { This decision } \\
\text { seems right in } \\
\text { the sense that } \\
\text { previously the } \\
\text { engine showed } \\
\text { starting } \\
\text { problem and } \\
\text { the problem } \\
\text { was resolved } \\
\text { from the engine } \\
\text { room. }\end{array}$ \\
\hline & \multicolumn{4}{|c|}{$\begin{array}{l}\text { Waste of valuable time: This transfer of control takes } \\
\text { usually 20-30 seconds and must be completed before } \\
\text { engine stopped. As soon as the lube oil pressure } \\
\text { reached desired state, the engine could have been } \\
\text { operable from the engine room. }\end{array}$} \\
\hline & 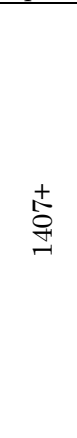 & 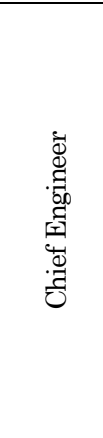 & $\begin{array}{l}\text { The Chief } \\
\text { Engineer could } \\
\text { have increased } \\
\text { engine rpm at } \\
\text { this stage. }\end{array}$ & $\begin{array}{l}\text { But the Master } \\
\text { cannot } \\
\text { determine his } \\
\text { course of } \\
\text { action. } \\
\text { Due to } \\
\text { language } \\
\text { barrier he } \\
\text { wasn't fluent } \\
\text { with the pilot } \\
\text { who was } \\
\text { navigating the } \\
\text { ship. }\end{array}$ \\
\hline 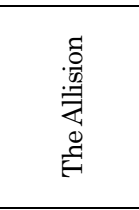 & 吉 & \multicolumn{3}{|c|}{$\begin{array}{l}\text { Engine power came back on } 1408 \text {. But the } \\
\text { crew realized very late that allision is } \\
\text { inevitable. The port bow of Bright Field } \\
\text { strikes a wharf adjacent to a populated } \\
\text { commercial area including a shopping mall, a } \\
\text { condominium parking garage and a hotel. }\end{array}$} \\
\hline
\end{tabular}




\subsection{Accident of MV Planet V}

The accident of MV Planet V took place on 26th May 2012 at the Westerschelde, The Netherlands. The motor vessel lost its engine power and collided with a towed pontoon while an Able-bodied Seaman (AB) lost his life trying to reduce the ship speed by dropping anchor [3]. Table 2 shows a list of major events that took place prior to the occurrence of the accident.

Table 2: Timeline of major events before collision of MV Planet V [3].

\begin{tabular}{|c|c|}
\hline Time & Event \\
\hline $16: 30$ & $\begin{array}{l}\text { The Chief Officer carried out a routine test of the navigation } \\
\text { systems on the bridge deck. Nothing unusual observed. }\end{array}$ \\
\hline $\begin{array}{l}\text { Next } 40 \\
\text { minutes }\end{array}$ & $\begin{array}{l}\text { Voyage preparation was made using a Voyage Plan (Before } \\
\text { departing for sea, the captain has to draw up a voyage } \\
\text { preparation document, which is referred to as Voyage Plan). }\end{array}$ \\
\hline $17: 10$ & $\begin{array}{l}\text { A tugboat MTS Vantage leaves for its destination with its } \\
\text { pontoon tow. }\end{array}$ \\
\hline $\begin{array}{l}\text { Next } 8 \\
\text { minutes }\end{array}$ & $\begin{array}{l}\text { The Pilot of the MTS Vantage contacts the Pilot of MV Planet } \\
\text { V by VHF to inform about the tugs intentions. }\end{array}$ \\
\hline $17: 18$ & Main engine of MV Planet V is started. \\
\hline $\begin{array}{l}\text { Next } 6 \\
\text { minutes }\end{array}$ & $\begin{array}{l}\text { At this time two auxiliary engines for the auxiliary generators } \\
\text { were running. The shaft generator was also running which was } \\
\text { used to provide power for the bow thruster. }\end{array}$ \\
\hline $17: 24$ & The ship departs the harbor. \\
\hline $\begin{array}{l}\text { Next } 17 \\
\text { minutes }\end{array}$ & $\begin{array}{l}\text { The Captain informed the engine room crew that the bow } \\
\text { thruster was no longer required. The Chief Engineer, therefore, } \\
\text { shut down the auxiliary engines and used the shaft generator } \\
\text { for necessary power. }\end{array}$ \\
\hline $17: 41$ & $\begin{array}{l}\text { MTS Vantage passes the Sloehaven harbor entrance with a } \\
\text { speed of } 6 \text { knots. }\end{array}$ \\
\hline $17: 45$ & $\begin{array}{l}\text { MV Planet V passes the harbor entrance. The speed was } 11 \\
\text { knots. }\end{array}$ \\
\hline $17: 48$ & $\begin{array}{l}\text { MV Planet } \mathrm{V} \text { is along the starboard side of the pontoon. The } \\
\text { speed of Planet } \mathrm{V} \text { was about } 10 \text { knots. }\end{array}$ \\
\hline $17: 48: 23$ & $\begin{array}{l}\text { The main engine of MV Planet V fails. Immediately the } \\
\text { electrical systems onboard failed and the ship went into total } \\
\text { blackout. }\end{array}$ \\
\hline \multirow{3}{*}{$\begin{array}{l}\text { Next } 16 \\
\text { seconds }\end{array}$} & The ship started to turn port after the electrical failure. \\
\hline & $\begin{array}{l}\text { The crew and the Pilot observed that the rudder angle indicator } \\
\text { showed starboard rudder angle. }\end{array}$ \\
\hline & $\begin{array}{l}\text { The Pilot of MV Planet V informs the Pilot of MTS Vantage } \\
\text { about the situation and requests 'full speed ahead' for the tug to } \\
\text { prevent collision. }\end{array}$ \\
\hline $17: 48: 39$ & $\begin{array}{l}\text { The Captain of Planet } \mathrm{V} \text { instructs } \mathrm{AB} \text { to return to forecastle, } \\
\text { and prepare the anchor. }\end{array}$ \\
\hline $17: 49: 34$ & $\begin{array}{l}\text { The Captain orders to drop the anchor via VHF. The pilot was } \\
\text { not consulted with about this. The intention of the Captain is to } \\
\text { slow down the ship and accelerate its turn to the port in an } \\
\text { attempt to pass the tug and the tow at its stern. }\end{array}$ \\
\hline \multirow{4}{*}{$\begin{array}{l}\text { Next } 21 \\
\text { seconds }\end{array}$} & $\begin{array}{l}\text { The tug started increasing speed and turning to port in an } \\
\text { attempt to increase its distance from MV Planet V. }\end{array}$ \\
\hline & The Captain orders AB not to run out of chain any further. \\
\hline & $\begin{array}{l}\text { AB tightens the anchor winch brake. Despite this the anchor } \\
\text { chain continues to run out at high speed. }\end{array}$ \\
\hline & $\begin{array}{l}\text { To apply additional force } \mathrm{AB} \text { climbed onto the electrical motor } \\
\text { of anchor winch. }\end{array}$ \\
\hline \multirow[t]{2}{*}{ 17:50:05 } & MV Planet V hits the pontoon amidships on its starboard side. \\
\hline & $\begin{array}{l}\text { After collision MV Planet V moved along the pontoon while } \\
\text { the anchor chain continued to run out. The loose bitter end of } \\
\text { the chain flew out of the sparling pipe and fell overboard. } \\
\text { AB standing on the electric motor was hit and fatally injured } \\
\text { by the anchor chain. }\end{array}$ \\
\hline
\end{tabular}

The timelines shown in Table 1 and Table 2 suggest that the accidents could have been prevented if appropriate decisions were made by the crew at the right time. For example, the allision of MV bright field could have been prevented if the Chief Engineer knew about the danger ahead and took emergency restart of the engine. On the other hand, in the Planet $\mathrm{V}$ case, if the auxiliary generators were kept running then the bow thruster could have been used to avoid the collision and the Seaman could have saved his life by avoiding the emergency anchor maneuver or standing in a different spot. Therefore, the case studies suggest that accidents are preventable if proper decision/actions deduced and implemented at the right time. In this view, the following section describes how a logic model can be constructed and can be utilized in analyzing accidents.

\section{Logic Model}

\subsection{What is Logic?}

Logic may be defined as the science of reasoning. However, this is not to suggest that logic is an empirical (i.e., experimental or observational) science like physics, biology, or psychology. Rather, logic is a non-empirical science like mathematics. Reasoning is a special mental activity called inferring, what can also be called making (or performing) inferences. A useful and simple definition of the word 'infer' - 'To infer is to draw conclusions from premises'. Inferences are made on the basis of various sorts of things - data, facts, information, states of affairs. In order to simplify the investigation of reasoning, logic treats all of these things in terms of a single sort of thing called 'statements'. Logic correspondingly treats inferences in terms of collections of statements, which are called 'arguments'. The definition of 'argument' that is relevant to logic is given as 'an argument is a collection of statements, one of which is designated as the conclusion, and the remainder of which are designated as the premises'. The reasoning process may be thought of as beginning with input (premises, data, etc.) and producing output (conclusions). In each specific case of drawing (inferring) a conclusion $\mathrm{C}$ from premises $\mathrm{P} 1$, $\mathrm{P} 2, \mathrm{P} 3, \ldots$, the details of the actual mental process is 
not the proper concern of logic, but of psychology or neurophysiology. The proper concern of logic is whether the inference of $\mathrm{C}$ on the basis of $\mathrm{P} 1, \mathrm{P} 2$, P3, ... is warranted (correct) or not $[15,16]$.

\subsection{Types of Logic}

Logics can be classified in several ways. However, one of the fundamental types are: (1) Deductive Logic and (2) Inductive Logic. Deductive logic is the process of reasoning from one or more general statements (premises) to reach a logically certain conclusion. The truth of the premises guarantees the truth of the conclusion and vice versa. Inductive reasoning (as opposed to deductive reasoning) is reasoning in which the premises seek to supply strong evidence for (not absolute proof of) the truth of the conclusion. While the conclusion of a deductive argument is supposed to be certain, the truth of the conclusion of an inductive argument is supposed to be probable, based upon the evidence given [16].

\subsection{Logical Arguments}

Based on the accident case of MV Bright Field a table of logical arguments are constructed and presented in Table 3. Similarly, Table 4 presents the logical arguments constructed based on the accident of MV Planet V. It may be noted that premises (P) are numbered where needed and the conclusions (C) are typed in italic.

Table 3: Logical arguments based on MV Bright Field accident case.

\begin{tabular}{|c|c|}
\hline Type of Logic & Premises and Conclusion \\
\hline Deductive Logic & $\begin{array}{l}\text { P1: Ground is nearby. } \\
\text { P2: Ship has speed. } \\
\text { P3: Ship is uncontrollable. } \\
\text { C: Ship will hit ground. }\end{array}$ \\
\hline Inductive Logic & $\begin{array}{l}\text { P1: Engine not delivering enough power. } \\
\text { P2: Rudder is not functional. } \\
\text { C: Ship is uncontrollable. }\end{array}$ \\
\hline Inductive Logic & $\begin{array}{l}\text { P: Engine not delivering enough power. } \\
\text { C: Ship is uncontrollable. }\end{array}$ \\
\hline Inductive Logic & $\begin{array}{l}\text { P: Rudder is not functional. } \\
\text { C: Ship is uncontrollable. }\end{array}$ \\
\hline Inductive Logic & $\begin{array}{l}\text { P: Engine automatic shutdown. } \\
\text { C: Engine not delivering enough power. }\end{array}$ \\
\hline Inductive Logic & $\begin{array}{l}\text { P: Engine manual shut down. } \\
\text { C: Engine not delivering enough power. }\end{array}$ \\
\hline Inductive Logic & $\begin{array}{l}\text { P: Lubricating oil pressure low. } \\
\text { C: Engine automatic shutdown. }\end{array}$ \\
\hline Inductive Logic & $\begin{array}{l}\text { P: Lubricating oil pump fails. } \\
\text { C: Lubricating oil pressure low. }\end{array}$ \\
\hline
\end{tabular}

Table 4: Logical arguments based on MV Planet V accident case.

\begin{tabular}{||l|l||}
\hline \hline Type of Logic & Premises and Conclusion \\
\hline \multirow{5}{*}{ Deductive Logic } & P1: Ship has speed. \\
& P2: Another ship is in collision course. \\
& P3: Ship is uncontrollable. \\
& C: Ship will collide with another ship. \\
\hline \multirow{3}{*}{ Inductive Logic } & P1: Ship has speed. \\
& P2: Engine shutdown. \\
& P3: Bow thruster shutdown. \\
& C: Ship is uncontrollable. \\
\hline \multirow{2}{*}{ Inductive Logic } & $\begin{array}{l}\text { P: Engine shutdown. } \\
\text { C: Faulty regulator. }\end{array}$ \\
\hline \multirow{3}{*}{ Deductive Logic } & $\begin{array}{l}\text { P1: Shaft generators shutdown. } \\
\text { P2: Auxiliary generators shutdown. }\end{array}$ \\
& C: Bow thruster shutdown. \\
\hline \multirow{2}{*}{ Deductive Logic } & $\begin{array}{l}\text { P: Commanded to shutdown auxiliary generators. } \\
\text { C: Auxiliary generators shutdown. }\end{array}$ \\
\hline \multirow{2}{*}{ Deductive Logic } & $\begin{array}{l}\text { P: Engine shutdown. } \\
\text { Shaft generators shutdown. }\end{array}$ \\
\hline
\end{tabular}

\subsection{Structure of Logic}

The logical arguments shown in the above tables are transformed into Prolog codes. The general structure of the predicates are shown below:

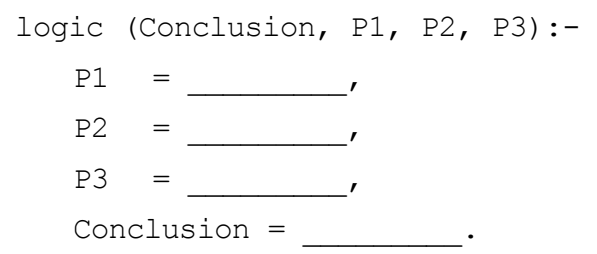

\subsection{Structure of query}

The query is used to enquire whether there will be any accident or not for a given set of facts. The structure of the query is given as follows:

$$
\begin{aligned}
& \text { how:- } \\
& \operatorname{logic}(C, P 1, P 2, P 3) .
\end{aligned}
$$

Hence, using the above mentioned argument and query structure it is possible to deduce and analyze accidents as described in the following sections.

\section{Results and Analysis}

This study represents ideal scenarios in order to explain the model in simplistic manner. The world that has been constructed in this study has some assumptions. Such as:

1. The crew of the ship is ideal i.e. they exercise all the regulations as it is and do not disobey any rule or conduct any crime.

2. 'Ground is nearby.' means the crew is able to see ground by bare eye.

3. 'Ship has speed.' means that the ship is in 
normal forward motion.

4. 'Ship is uncontrollable.' means there is no possible way of keeping desired ship's speed and heading.

5. In case of emergency bow thruster is able to change course and avoid collision with another ship.

Three different sets of results are presented in this study for simple demonstration. The first case is where a ship is in normal forward motion which is given as a fact 'Ship has speed.'. The ship is sailing through inland waters where the crew can easily see the ground. The ship is considered to have functional rudder and will remain functional during the study. Under the circumstance, a query on how an accident may occur will result in a set of logical outputs which as shown in Fig. 2.

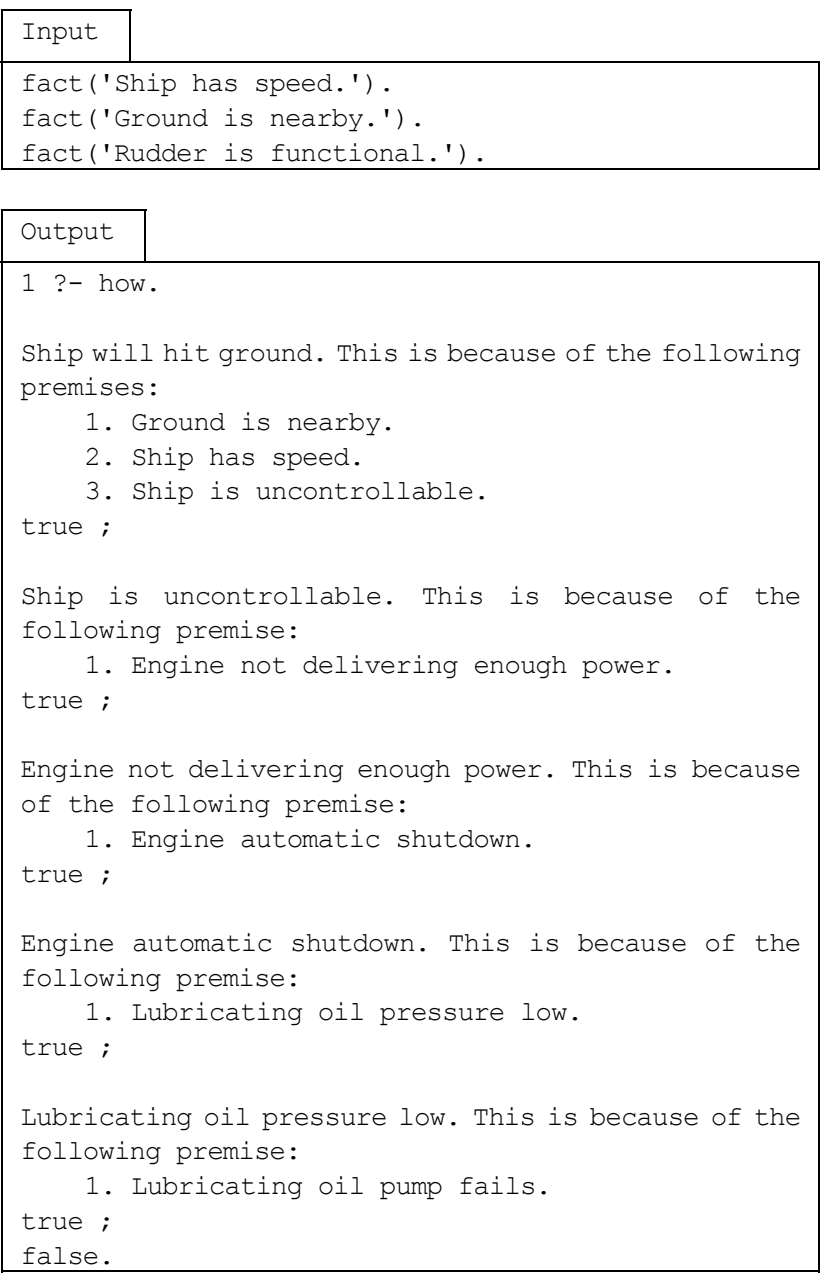

Fig. 2: Input and output for Case 1

The output of the logic model is executed through 'how' predicate which is discussed in the earlier section. This predicate attempts to find a match within the constructed logic world with the given facts. At first it obtains a match and delivers the first logical conclusion that the 'ship will hit ground'. The predicate generates the reasoning based on three premises 1. Ground is nearby, 2. Ship has speed and 3. Ship is uncontrollable. Then the 'how' predicate backtracks and attempts to find another logic which may match with the facts. Hence it concludes that 'Ship is uncontrollable' because 'Engine not delivering enough power'.

In this way the 'how' predicate continues until all the logic predicates are exhausted. This analysis suggest that the ship crew may comprehend the possible danger through the expert system and if possible may take necessary action which are allowable within the regulations to avoid an accident. For example in this case the Chief Engineer may have reacted much earlier by manually restarting the engine power rather than wasting time in transferring engine control.

In the second case the input facts are changed as shown in Fig. 3. It is considered that there are two ships in collision course. One of the ship has a faulty engine regulator and that ship has shut down its auxiliary power units after leaving port. The ship has a bow thruster which are usually powered using the auxiliary power units and can also be powered using engine shaft generator.

Now by posting a query 'how' the accident may occur will result in a set of arguments outputs. At first the 'how' predicate obtains a match and delivers the first logical conclusion that the "ship will collide with another ship' because 1 . Ship has speed, 2. Another ship is in collision course and 3. Ship is uncontrollable. Then the how predicate backtracks and attempts to find another logic which may match with the facts. Hence it concludes that 'Ship is uncontrollable' because 1. Ship has speed, 2. Engine shutdown and 3. Bow thruster shutdown. Similarly the logical arguments are deduced which are differ from case 1 . The analysis suggest that ship became uncontrollable because of the failure of engine regulator. Since the auxiliary power units were shut down, the bow thruster was not operational. In an ideal world such a scenario this will lead to an accident. 


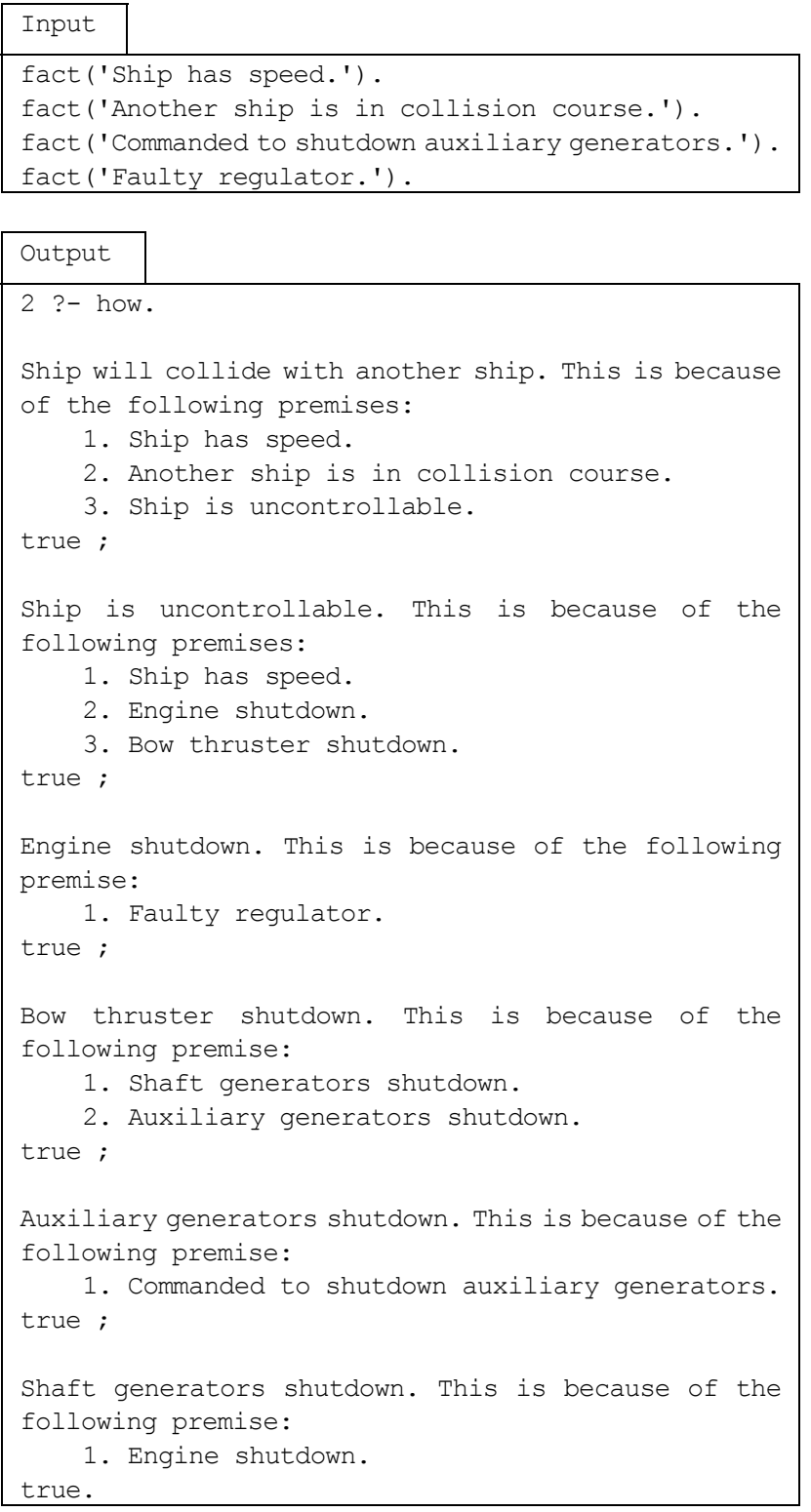

Fig. 3: Input and output for Case 2.

In this hypothetical model world it is assumed that the bow thruster action is sufficient to maneuver the ship out of collision course. Therefore, if the auxiliary power units were kept running, it can be logically deduced that the ship will not be uncontrollable anymore and hence the ship may avoid a collision. Fig. 4 shows this analysis where the fact('Commanded to shutdown auxiliary generators.') is no longer true in the input section. Therefore, logically it can be deduced that the bow thruster is operable and emergency maneuvering no longer necessary. As the crew are ideal crew, they will apply the bow thruster to change course and avoid a collision. Therefore, the 'how' predicate could not match any of the logic that can prove the truth of an accident. Hence, the output deduces nothing i.e. no accidents in the ideal world.

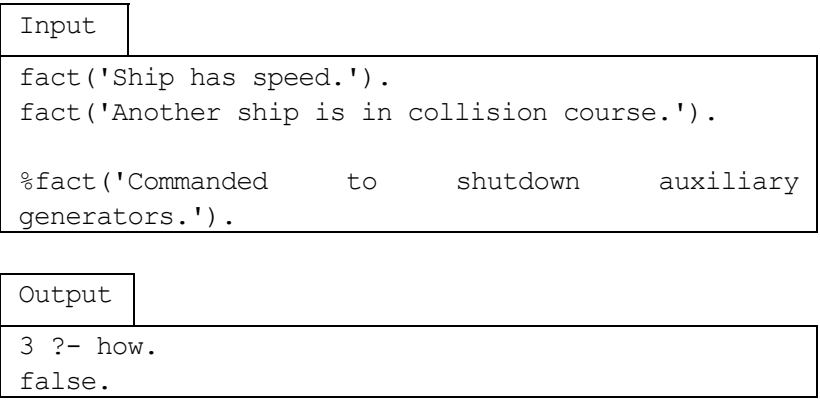

Fig. 4: Input and output for Case 3.

Hence, the above results shows that it is possible to predict and analyze accidents with possible causes in the logic programming domain. Therefore, the new method Logic Programming Technique (LPT) can be further developed and utilized in future.

\section{Conclusions}

This study presented a new accident analysis technique and explained the occurrence of ship accidents associated with engine failure. The methodology of this technique is very simple. Knowledge is represented by simple deductive and inductive logics in Prolog environment. A simple query is formulated and utilized to generate sequence of events as outputs for an accident event. The study revealed that accidents, which are thought to be occurred due to engine failure alone, have profound connections with the crew actions as well.

The study applies ideal cases which need significant modifications to be applied in real life scenario. For example, the logic model presented here is static and it is unable to deal with dynamic facts within the predicates. However, it has to be kept in mind that the objective of this research is to investigate the potentiality of logic programing technique in maritime accidents. So far the research findings appear satisfactory and the future potentials are very good. For future studies the following recommendations are made:

1. Consideration of crew actions and perceptions in predicate logics could yield 
more realistic modelling. According to the scenario demand, such action-perception predicates can be used for ship crews both individually and cumulatively.

2. Consideration of a dynamic world where the facts are constantly changing and comprehended by the crew through perception predicate could result in a more dynamic and realistic output.

3. For future applications, integration of ship maneuvering numerical simulations along with the logical deductions will be very useful. This will enhance the applicability and easy understanding of the system.

\section{References}

[1] "Allision of the Liberian Freighter Bright Field with the Poydras Street Wharf, Riverwalk Marketplace, and New Orleans Hilton Hotel in New Orleans, Louisiana December 14, 1996", Marine Accident Report, Notation 6885A, National Transportation Safety Board (NTSB), (1998).

[2] "Brace for Impact", System Failure Case Studies, National Aeronautics and Space Administration (NASA), Vol. 4(10), pp. 1-4, (2010).

[3] "Fatal Accident Onboard Planet V during Emergency Anchoring", Report by the Dutch Safety Board, (2013).

[4] "Analysis of Marine Accidents by Logic Programming Technique", Awal, Z.I. and Hasegawa, K., Proc. of the International Symposium on Marine Engineering (ISME), Paper-ISME127 (USB Drive), (2014).

[5] "Revisiting Heinrich's Law", Ward, R.B., Proc. of Chemeca 2012 Conference, pp. 1179-1187, (2012).

[6] "A Review of Accident Modelling Approaches for Complex Critical Sociotechnical Systems", Qureshi, Z.H., Report number DSTO-TR-2094, Defense Science and Technology Organisation, Australian Government, (2008).

[7] "A Study on Inland Water Transport Accidents in Bangladesh: Experience of a Decade (1995-2005)", Awal, Z.I., Int. J. of Small Craft Technology (IJSCT), Vol. 149(B2), pp. 35-40, (2007).

[8] "Collision of Marine Vehicles in Bangladesh: a Study on Accident Characteristics", Awal, Z.I., Islam, M.R. and Hoque, M.M., J. of Disaster Prevention and Management, Vol. 19(5), 582-595, (2010).

[9] "An Overview of Maritime Waterway Quantitative Risk Assessment Models", Li, S., Meng, Q. and Qu, X., Risk Analysis, Vol. 32(3), pp. 496-512, (2012).

[10] "Occupational Injury and Accident Research: A Comprehensive Review", Khanzode, V.V., Maiti, J. and Ray, P.K., Safety Science, Vol. 50(5), pp. 1355-1367, (2012).

[11] "Accident Analysis by Logic Programming Technique", Awal, Z. I. and Hasegawa, K., Proc. of the 25th European Safety and Reliability Conference, ESREL 2015, pp. 13-21 (CD-ROM), (2015).

[12] "Bridge Resource Simulator - A New Tool for Ship Accident Analysis", Awal, Z.I. and Hasegawa, K., Proc. of the Japan Society of Naval Architects and Ocean Engineers (JASNAOE) 2013 Spring Meeting, Vol. 16, pp. 51-54, (2013).

[13] "A Concept for Expert System Based Accident Prediction Technique for Ship Maneuvering", Hasegawa, K. and Awal, Z.I., Proc. of the Int. Maritime Conference on Design for Safety (IDFS 2013), DFS-2013-044 (USB Drive), (2013).

[14] "Application of logic programming technique on maritime accident analysis", Awal, Z.I. and Hasegawa, K., Proc. of Int. Conference on Ship and Offshore Technology (ICSOT), pp. 59-66, (2014).

[15] "Artificial Intelligence A Modern Approach", Russel, S. \& Norvig, P., Prentice Hall, (2010).

[16] "Symbolic Logic: A First Course", Hardegree, G. M., McGraw-Hill College, (1999).

\section{Authors}

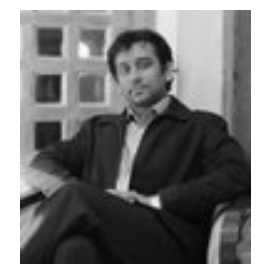

Zobair Ibn Awal is currently Doctoral Candidate at the Osaka University, Japan His research interests focus on accident theory and accident prediction techniques.

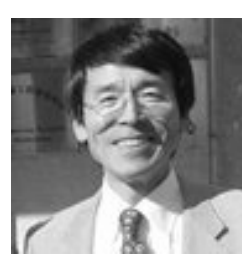

Kazuhiko Hasegawa is Professor of Department of Naval Architecture and Ocean Engineering, Osaka University, Japan. His major research field is ship maneuverability and its control. 